\title{
A LOOK AT THE LEASE FROM THE LESSOR'S POINT OF VIEW
}

\author{
J. B. DEA*
}

Speculation and exploration are still apt words to describe the oil and gas industry which spends a great deal of time and money drilling small holes in prairie rock farms and cow pastures in the hope of finding commercially profitable deposits of oil, gas and related substances. It is the purpose of this paper to speculate on and explore the petroleum and natural gas lease from the point of view of the lessor. It is not to be an examination of leases to find therein the fatal flaw, but instead to consider some clauses often found in leases and to explore the perhaps diminishing world of implied covenants which have affected leasing in the United States and lease forms in Canada.

The proposition that the substantial consideration for the granting of a petroleum and nautral gas lease is the provision for a royalty payment on production is well recognized in the United States and has resulted in the introduction of implied covenants by the lessee to accomplish reasonable development of leased lands. However, in Canada there are few examples of the courts implying covenants into the oil and gas lease, and this, it seems, is due not to any great differences in the legal philosophy of the two countries, but because long before Leduc was discovered, American courts and oil companies had faced the basic implied covenants and consequently new clauses and procedures were being adopted to avoid or reduce the effect of the most objectionable covenants. These new leases avoiding implied covenants were subsequently exported to Canada at a time when the oil industry was just beginning to make its presence felt. Also, the so-called rule of capture has not achieved the same pre-eminence in Canada as it did in the United States, principally because of the widespread existence of conservation legislation in the prairie provinces.

Those clauses in Canadian leases which require the lessee to drill, or allow the postponement of drilling for certain periods of time dependent upon the payment of rentals, exist because American courts, in examining leases without such covenants to drill within a specified or reasonable time, found implied covenants on the part of the lessee to develop the lands by drilling or otherwise within a reasonable period of time. Faced with these decisions, the United States lessee began to insert covenants in the lease dealing with drilling obligations. By inserting covenants to drill within a specified time, the lessee avoids the danger of a court finding that there was an implied covenant which the lessee had unwittingly breached. Therefore the lessee is much more certain of his obligations under the lease and less likely to breach them. Provision for the payment of rentals in order to postpone drilling is done for the same purpose.

Merrill, in his Covenants Implied in Oil and Gas Leases sets out the four principal obligations that the American court have implied into the oil and gas lease. They are:

1. The implied covenant to drill an exploratory well.

\footnotetext{
- Barrister and Solicitor, Fleld, Hyndman \& Company, Edmonton, Alberta.
} 
2. The implied covenant to drill additional wells.

3. The implied covenant of diligent and proper operation of the wells and of marketing the product if oil or gas is discovered in paying quantities.

4. The implied covenant to protect the leased premises against drainage by wells on adjoining land.

While Canadian courts have not to any noticeable degree explicitly found implied covenants that are so much a part of American law, nevertheless the oil and gas lease in Alberta is very much subject to clauses, terms and conditions which do not appear in the lease form itself. Section 5 of The Oil and Gas Conservation Act ${ }^{2}$ and other sections of that legislation provide that where there is a conflict between the terms of any lease and the provisions of the Oil and Gas Conservation Act, the provisions of the Act shall apply. The real purpose of that Act is conservation and not development, and so while development is encouraged, it is always subject to conservation measures and consequently no oil and gas lease can be properly read or understood without reference to that Act.

$\mathrm{By}$ and large, the lessee is familiar with the provisions of the Oil and Gas Conservation Act. He knows that the right to drill is restricted as to location and number of wells, and that even if he has the good fortune to find oil or gas in commercial quantities, he cannot produce the same unless he controls a spacing unit as defined by the Board. Further, he knows that if the land covered by his lease does not constitute a spacing unit, he can force pool. $\mathrm{He}$ is also aware of his right, limited though it may be, to place the lands into a unit operation. The procedures for drilling and production are to a considerable extent set out in the Act, and these are gain matters of which the lessee has knowledge and of which, by and large, the lessor does not. In fact, often times a lessor, not knowing about the Oil and Gas Conservation Act and its regulations, will be under the grave misapprehension that his lease contains the entire agreement between him and his lessee. It is submitted that some of the problems which cause difficulties between the lessor and the lessee could be avoided by the lessee indicating in the lease by a clause, or clauses, the significance of this legislation.

Some years ago a farmer wanted to lease his land to an oil company which wanted to drill through an abandoned well to a new formation to produce gas. The land was close to the City and the farmer looked forward to developing the surface of the land for commercial purposes. The farmer was therefore anxious to provide very restrictive provisions with respect to drilling and production rights, and he provided in the lease that in the event that he were able to sell the land for development purposes, the oil company would be required to abandon its wells and cease production so that a sale of the land for development purposes would not be endangered. The farmer did not know that without the assistance of the Oil and Gas Conservation Board he could not compel the lessee to abandon the well so that the land could be sold for commercial purposes. There are undoubtedly many other cases where lessor-lessee relationships have been unnecessarily injured because of the lessor's ignorance of relevant

1 Merrill, Covenants Implied in Oil and Gas Leases, (2nd ed.) 1964, at p. 23.

2 R.S.A. 1955 c. 227. 
statutory and regulatory provision. Further reference to the effects of conservation legislation will be made in a subsequent part of this article.

Lately we have seen several cases go to the Supreme Court of Canada interpreting the habendum clause in oil and gas leases. In particular, these cases involved a continuation of the lease beyond the primary term. The cases in the United States with respect to the habendum clause and implied covenants are interesting and worthy of note in this context.

Where a lease contains lands that are not contiguous and all of the development is on one of the tracts, does the production from that tract continue the lease beyond the primary term insofar as the other tract is concerned? Merrill ${ }^{3}$ would suggest that it does not. He cites the following passage in support of his view: ${ }^{4}$

... unless the Plaintiff's tract was to be developed sometime there was no reason to include it in the lease, and as it stands it is of no value to Defendants. Unless the Defendants had a bona fide intention to prospect and develop this tract, they had no proper purpose in leasing it and to cancel the lease will do them no injury. While equity abhors forfeitures, it likewise abhors injustice.

Since Plaintiff's lands are burdened with an oil and gas lease, he is entitled to have those lands prospected for oil and gas within a reasonable time.

It is not difficult to envisage an Alberta court following such a decision.

Another point which follows from the first but is more difficult is that which deals with the production of only one of the substances covered by the lease. Under the normal petroleum and natural gas lease, the production of say gas would keep the lease alive under the thereafter clause ("production of any of the leased substances"). By virtue of the terms of the thereafter clause this is so even though the spacing unit from which the gas is being produced may not cover all of the land covered by the lease and even though the lessee might be able to produce gas or oil from another formation under the land.

Merrill ${ }^{5}$ indicates that there is an implied covenant requiring a lessee to attempt to develop production from the lower strata where the data available gives reasonable grounds for believing that those lower strata may contain profitable deposits. He does state, however, that where the lease is of both oil and gas there is no need to continue exploration once production of one of the substances has been achieved. He indicates that the law may be changing in this respect and states: ${ }^{6}$

A variant of the problem as to exploring other strata arises in connection with leases which by their terms extend to more than one mineral. While production of any one of the substances covered by such a lease may be adequate to preserve the leasehold where it is specified that it shall continue so long as any of the minerals are produced, do not the implied covenant obligations require exploration within a reasonable time for each mineral embraced within its terms, at least wherever there is reasonable cause to infer that the substance might be found on the premises? What authority exists seems to point in this direction.

Whether or not a Canadian court would accept this analysis, it is clearly in the interest of the lessor to grant separate leases for gas and oil rather than to give one lease covering both. The lessee's position is difficult to assess. If the implied covenant to develop requires, as suggested, the development of other formations and perhaps the development of other minerals covered by the lease in order to continue the lease with

8 Merrill, Covenants Implied in Oil and Gas Leases, (2nd ed.) 1964.

1 At p. 65.

At p. 175 .

B At p. 34 . 
respect to those minerals beyond the primary term, then many lessees under existing leases in Alberta would find themselves in an undesirable position. This is so because the existing clauses are purposely designed to include as many substances as possible.

Perhaps in order to remove all doubts, the answer is to provide that the lease is severable insofar as it relates to particular substances included therein and also as to particular formations and even as to spacing units. In this way, a company producing, say, oil from a spacing unit of one legal subdivision where the lease covers oil and gas in a full section might be in breach of the implied covenant insofar as other substances and other formations are concerned, but would not be in default insofar as the producing area is concerned. In such a case, a lessee who has not developed the other leased substances or even the substances produced from other spacing units and/or other formations prior to the expiration of the primary term would be hard put to find anyone very sympathetic to his plight.

In a minor way, the Canadian Pacific Oil and Gas Limited standard lease does consider these matters by restricting the estate which it conveys to a particular geological formation, and the pooling clause provides a restricted right to carry forward the lease under the thereafter clause.

In the United States, there is an implied covenant to drill an offset well once production has been encountered on an adjoining tract, in order to prevent drainage of the leased substances under the said land by a well situate on other lands. As indicated, however, the better opinion appears to be that where oil and gas are granted by the same document the development by the operator of either substance is a sufficient compliance with the covenant to develop, and both substances need not be developed at the same time. Whether the operator of an oil well under a petroleum and natural gas lease can avoid the implied covenant to drill an offset well for gas appears in doubt. The covenant is, of course, not so much to develop the leased lands as to protect the lessor of the lands against drainage. Merrill states: ${ }^{7}$

There is in every lease on land for the production of oil and gas a condition implied when not expressed that when the existence of either of these valuable mineral substances in paying quantities becomes apparent from operations on the premises leased on or adjoining lands, the lessee shall drill such number of wells as in the exercise of sound judgment he may deem reasonably necessary to secure either oil or gas or both for the mutual advantage of the owner of the land and of himself as operator under the lease, also for the protection of the lands leased from drainage through wells on adjoining or contiguous lands.

Oil and gas leases in Alberta invariably contain an offset clause the purpose of which is to vary, if not to restrict, the operation of the implied covenant. These offset clauses differ considerably. One lease will contain no covenant to drill an offset at all unless petroleum is being produced on adjoining lands. Still another makes the drilling of an offset, where the adjoining well is a gas producer, conditional upon an adequate and commercially profitable market for the natural gas produced from the offset well. Differences are also noticed in the areas affected by the offset provision. Some leases refer to laterally adjoining legal subdivisions, others to laterally adjoining spacing units, and still others to laterally adjoining or diagonally adjoining spacing units. Of interest is the "lessor"

7 At p. 150. 
lease, characteristic of the Hudson's Bay Oil and Gas Lease. It imposes a very general duty on the operator to take steps to protect the owner against drainage. The consequences of failure to drill an offset well are equally divergent. Some leases provide for the surrender of the adjoining legal sub-division, some for the surrender of the adjoining spacing unit, some for the surrender of the adjoining spacing unit insofar as it relates to the zone from which the drainage is occuring, and some (Canadian Pacific Oil and Gas) for the surrender of the lease except the spacing unit and zone from which the operator may already be producing.

When the lessee decides not to drill an offset well the consequences to the lessor deserve consideration.

No operator can be regarded as unreasonable because he wishes to avoid incurring drilling expenses which, at most, produce a marginal profit and which may, because of marketing difficulties, result in tying up capital in a shut-in well. If it was clear to the operator that the offset would result in a commercially profitable venture, he would of course not object to the expense. In setting up unit agreements, engineers and geologists take upon themselves a most formidable task in determining the amount of oil and gas in place and apportioning it between various owners. If it is feasible from an engineering standpoint to tdetermine the amount of oil and gas in place under such circumstances, cannot engineers determine in a similar manner the amount of drainage suffered by any particular land resulting from a well on other lands? If the drainage could be determined, and if it could be said to be uneconomical for the lessee to conduct his own drilling operations, then it would appear reasonable to require the operator and owner of the producing well to account to the lessor and lessee on the offset property for that proportion of the production referable to the offset property-another inroad on the rule of capture, to be sure, but is it not preferable, from the point of view of the lessee, to drilling an offset or losing a lease? Is it not also preferable, from the point of view of the lessor to getting back an adjoining legal sub-division or spacing unit upon which nobody is likely to want to start drilling? No doubt compulsion would be required, but in an industry that has accepted forced pooling, forced utilization and the restrictive and detailed regulations which now exist, the complusive nature of the proposition seems to be the least of the problem.

It is now proposed to consider some clauses which appear in the usual oil and gas lease.

\section{ROYALTY}

In the past, most leases reserved to the lessor a one-eighth royality, with some exceptional leases providing for a royalty as high as one-sixth. On the face of it, one would expect the royalty to be negotiated at oneeighth or less where the area in question has no previous record of mineral production, and higher than one-eighth when mineral production appears more probable. These variations in the probabilities of finding commercial production have generally, in the past, found expression through the bonus consideration. In one case it is alleged that a bonus consideration in excess of $\$ 1,000,000.00$ was paid for a ten-year primary term lease of one-quarter section in Alberta. Whether this system, which 
has in the past been accepted by lessor and lessee without too much question, will continue in the future is in doubt. The federal Income Tax Act now makes bonus payments taxable income in the year of receipt. The result of this relatively recent change in legislation can be catastrophic. A lessor wishing to acquire a tax free bonus payment of $\$ 250,000.00$ would have to receive as actual bonus something in excess of $\$ 1,000,000.00$. These tax consequences will surely cause the lessor to turn away from the bountiful bonus payment, and look instead to a method of spreading his fortune over the years. He may attempt to accomplish this spreading of income by dealing differently with bonus payments, or the lessor may attempt to adjust the royalty percentage in accordance with the probabilities of finding commercial production. Consequently a higher royalty will replace the substantial bonus considerations common in days of yore.

Discussions of royalty almost always lead to a consideration of the various methods employed by lessees in Alberta to compute royalty. Some provide for a royalty in kind without more, whereas some provide that royalty in kind shall be treated by the lessee in the same manner as the lessee's share of production. Many leases provide for payment of royalty in money only, the amount being based on the leased substances "produced and marketed from the said lands." Often times gas is treated differently than oil. Some leases provide for the leasing of all mineral substances found in association with gas and oil, but make no reference to the royalty to be paid thereon, while others stipulate a royalty of 8 or 10 per cent on other minerals.

Variations in methods of computing royalty are probably unavoidable where the lessor writes the lease, but it is rather remarkable that after all these years the oil and gas industry has not arrived at some common formula for computing royalty. If, as expected, the percentage of royalty reserved to the lessor becomes a more significant factor in negotiations than it is at present, it is submitted that a common formula for computing royalty would be of value.

\section{INFORMATION}

A noticeable variation between a lease prepared by a lessor and a lease prepared by a lessee is found in the information which the lessee is required to give the lessor. In the leases prepared by the lessee, the lessor is generally not authorized to receive any information and must in fact rely entirely upon the lessee to determine not only the conduct of the operations but the actual computations of royalty. On the other hand, the leases prepared by lessors require detailed information with respect to drilling, production, marketing and, of course, royalty computations.

This information in a large number of cases would be of little or no value to the lessor, but in some cases its value is of considerable moment for the following reasons:

1. By and large, the information will show whether or not the lessee is conducting his drilling operations in a prudent, reasonable and, perhaps more important, non-negligent manner.

2. The information may disclose facts tending to show that one or 
more of the substances covered by the lease occur in higher or lower formations or are likely to occur there.

3. The information may disclose valuable substances in place which have not been covered by any particular lease, i.e. potash, iron ore, uranium, etc.

To a greater or lesser extent, this information is now given by the lessee to the Oil and Gas Conservation Board, but the Board has, of course, no duty to bring to the attention of the lessor any of the information disclosed to it, and it is questionable whether the lessor has any right to acquire the information from the Board or whether the Board has any right to give the information to the lessor. The Board gets the information in order to determine its conservation policies and not for the purpose of assisting the lessor to compel the lessee to perform the convenants in his lease, whether expressed or implied.

Lessees probably want to avoid the production of such information, not so much to keep it away from the lessors, as to keep it away from other companies and other prospective lessors. No lessor could seriously object to secrecy for this purpose. Stll, the lessor runs the very real danager of being unable to determine whether or not the lessee is performing the express or implied covenants of the lease when such information is not made available to him and when he has no way of compelling its production.

\section{Shut-In Wells}

The shut-in well clause is a further clause put into the lease to avoid the rigors of the implied covenant to develop. The lease is then kept alive by the payment of a "royalty" which is normally equivalent to the delay rental. There has always been a question in the United States concerning the adequacy of the consideration for postponing further drilling. Where delay rental is paid the courts have found the consideration to be adequate. However, payments of less than the delay rental have been regarded by some courts at least, as an insufficient compliance with the covenant to drill.

As in the case of the offset well, the shut-in provision appears to be in the best interests of both the lessor and the lessee. That is, it is not in the interest of either to produce to a weak market thereby making it weaker. The lessor's interest becomes adversely affected when the shut-in clause operates to continue the entire lease during the shut-in period, even though the substances shut in may be only one of several substances leased. Similarly his interest is prejudiced where the substance that is shut in is only typical of that particular spacing unit and not of all the lands leased or if, which is quite likely, the production is from one formation only and any number of the leased substances might be produced from other formations.

\section{Poourng}

Pooling brings into direct conflict the implied covenant to develop the lesaed lands and the implied covenant to market the product. The conflict occurs as a result of conservation legislation which restricts the 
production from a spacing unit and may determine where a well will be drilled or which of one or more wells in a spacing unit will be the producer. It is now beyond doubt that the legislature favours pooling and conservation, and so an operator in order to comply with the implied covenant to market and produce must often pool the lands in his lease with other lands. As no other production from the spacing unit with regard to that particular formation will be allowed it is inconsequential whether the actual wellsite is on the leased lands or on other lands.

Whether the decision of the courts in such cases as the Gibbard ${ }^{8}$ case and the Gunderson ${ }^{\theta}$ case can be said to be a denial of the implied covenant to market is in doubt. Such cases are surely a reminder, though, of the strong feeling which the Courts have for procedures which they consider tend to tie up land and to postpone development. It is submitted however, that when pooling is restricted to spacing units which are determined by governmental authority, the result of these decisions is unfortunate. Of interest here is the Canadian Pacific Oil and Gas lease which provides in its pooling clause that where none of the leased substances are being or are capable of being produced from the said lands at the expiration of the primary term, then the lease expires except as to the geological formation included in the spacing unit which is covered by a well on other land. It is quite apparent that this type of clause is in the best interests of the lessor.

\section{UNITIZATION}

Unitization as a method of producing and marketing the leased substances in very widespread in Alberta. In view of the legislation in force, the principal objections to unitization from the lessor's point of view must be that by and large the unitization of a particular substance produced from a particular formation has the effect of continuing the lease for all formations and all substances (subject to the query advanced earlier whether there may be an implied covenant to drill for other substances)..$^{10}$ The other objection which is of more practical significance is that the assignment of tract factors sometimes appears to depend more on the ability to negotiate than on the information produced by geologists and engineers. One result is that the lessor is pretty well saddled with the factor negotiated by the lessee, who for his own legitimate reasons may be willing to give and take on one part of the unit in order to gain an advantage elsewhere. Consequently the tract factor assigned may not be in the best interests of the lessor. The lessor can properly be said to be caught in the middle in these circumstances.

The responsibilities of the lessee to the lessor under the implied covenants are, where the property is unitized, surely varied if not avoided by strong conservation legislation. Merrill states: ${ }^{11}$

The increasing incidents of public regulation upon the production of oil and gas presents numerous occasions for the application of implied covenant principles. These employments may seem novel, but the underlying principles remain unchanged. The lessee owes to the lessor the obligation of due diligence in the exploitation of the leased premises for their common benefit. The intervention of public regulation simply means that the lessee must perform this duty in the

8 Shell Oil Co. Ltd. v. Gibbard, [1961] S.C.R. 725

9 Shell Oil Co. Ltd. v. Gunderson, [1960] S.C.R. 424.

10 Ante p. 211.

11 Merrill, at p. 269. 
hearing rooms of administrative agencies and in the courtrooms as well as in the field.

It seems very clear that the lessee is required to take all reasonable measures to realize the greatest production from the premises that is attainable under the applicable administrative rules. If he fails to perform an act reasonably in his power which would increase his allowable production, the lessor should be entitled to recover the royalty which would have accrued had the lessee been "on his toes". Moreover these regulations, while binding upon both the lessor and the lessee to the extent to which they are valid, do not abrogate the legally sanctioned race to reduce oil and gas to possession which goes on under the name of "the law of capture" ...

... The lessee who has charge of the operations will be more conversant with the conditions which make particular regulations improper or which may demand the granting of an exception. He has at his command the data and the technical staff necessary to make an adequate presentation. Hence, it seems clear that if an operation which ordinarily would fall within the scope of the implied covenant obligation is forbidden by rule or by regulatory order inappropriate in operation, the lessee to avail himself of the prohibition as an excuse for his default must show either that he has exhausted all the remedies available to him to prevent its promulgation or to procure relief from its restrictions or that its application to the operation in question is so clearly unexceptionable that either direct attack or petition for revision or exemption would be utterly without chance of success.

\section{Default}

Those provisions of the lease which prevent the cancellation of the lease upon default are surely justified insofar as such cancellation would affect a producing well or a spacing unit required for a producing well on some other lands. Where, however, the "no cancellation on default" clause relates to other portions or formations of the lands covered by the lease the provisions are less justifiable. In demanding a right to cancel on default under some circumstances, the lessor is aware that the courts have an inherent power to relieve against forfeiture and furthermore that the law "abhors a forfeiture". The lessor must find himself in a very difficult situation indeed when his remedy on default is restricted to damages, especially where he is asking for damages for breach of covenant for further development. How a lessor would establish the quantum of damages under such circumstances is a matter of some concern.

\section{AsSIGNMENTS}

Assignment clauses should do much more than they now accomplish. Assignments of particular formations or a spacing units in a particular formation should be encouraged. Certainty will brings with it marketability, and this is to the advantage of both the lessor and the lessee. Whether present assignment clases accomplish this purpose as well as they might is doubtful. The assignment by the lessee of a partial interest in the whole of the lease creates a problem only where there is a stipulation providing that the lease will terminate only as to the assignees interest where he has failed to meet his obligation to pay rentals. The assignments of particular portions of the lease on a surface basis are not quite so difficult, but where the part assigned does not form a spacing unit and there is a termination for failure to pay rentals, the result is unduly harsh on the lessor. On the other side of the coin, it has been suggested that such clauses purport to vary the habendum clause and to be effective should be set forth therein. If this is correct, then the nonpayment of a portion of rentals by an assignee would result in a termination of the whole lease and not just of the assignee's interest. Prohibitions 
against assignments by the lessor appear to be an undue restriction on the right to alienate property. A prohibition restricting the size of the partial interests assigned to say one per cent gross royalty or one-half per cent gross royalty would be more fair to the lessor and be not unduly onerous to the lessee.

\section{Conclusion}

Whether the American experience with implied covenants in the areas of further development and marketing will be found applicable to the Canadian scene remains largely to be seen, but it is perhaps to be expected that as the oil and gas industry advances to a new and more sophisticated role in the freehold areas of Alberta under the requirements of unitization, secondary recovery and marketing, some of the American experience perhaps in a varied form will make itself felt. 